\title{
Hybrid Model Of Structural Equation Modeling PIs And RFM (Recency, Frequency And Monetary) Model To Improve Bank Average Balance
}

\author{
Jerry Heikal', Vitto Rialialie ${ }^{2}$, Deva Rivelino ${ }^{3}$, Ign Agus Supriyono ${ }^{4}$ \\ Bakrie University, Indonesia ${ }^{1,2}$ \\ University of Raharja, Indonesia ${ }^{3,4}$ \\ e-mail: jerry.heikal@bakrie. ac.id ${ }^{1}$, rialialievitto@yahoo.co.id ${ }^{2}$, deva.rivelino@raharia.info ${ }^{3}$, \\ ignatius@raharia.info ${ }^{4}$
}

Jerry Heikal, Vitto Rialialie, Rivelino, D., \& Ign Agus Supriyono. (2021). Hybrid Model Of Structural Equation Modeling Pls And Rfm (Recency, Frequency And Monetary) Model To Improve Bank Average Balance. Aptisi Transactions on Technopreneurship (ATT), 4(1), $1-8$.

DOI: https://doi.org/10.34306/att.v4i1.221

\begin{abstract}
As business actors, entrepreneurs certainly need bank products and support that provide fast and easy services with a network that is widespread in Indonesia. In this study, the Structural Equation Model (SEM) identifies transactions that affect the average balance. The purpose of RFM segmentation on selected transactions is to understand the customer segment scores and build a marketing strategy for each segment with different loyalty levels for Financial results from a higher Average Balance. The segmentation results found three categories of drivers, namely the High Recency, Mid Recency, and Low Recency categories. High Recency is considered as an active Customer where the campaign category can cross/up-selling and promotion according to their Frequency and Monetary category. The Mid Recency category is considered as Risky customers whereas the campaign category can be a retention program according to their Frequency and Monetary. Finally, Low Recency is considered a Churn customer where the campaign category is reactivation.
\end{abstract}

Keywords: Bank, Structural Equation Modeling, Recency, Frequency, Monetary, Business Saving Product.

\section{Introduction}

SEM or Structural Equation Model was discovered in 1978 by Joreskorg, the development of SEM PLS was carried out by World in 19855 and Lomoller 1989 aimed at maximizing the variance to endogenous lethal variant. However, there is a difference that covariance-based SEM has another purpose in producing a covariance matrix with theory without having to focus on variance and has been applied to other fields including companies [1]. The development of the marketing of banking products has become very competitive and important. The growth of the banking industry has also shifted from offering their products and services to customer-focused relationship marketing to increase their loyalty. Increased loyalty Customers are highly expected to increase the average balance of customers, especially in this study of Bank XYZ's business savings products and increase the effectiveness of the campaign strategies carried out. Berdasarkan goal of customer loyalty, the company's financial 
growth is proven through an increase in loyal customers [2]. Satisfied customer is feeling, but customer loyalty is behavioral. Where the behavior shown is a plus that the company gets for customer loyalty to the services provided. For that, we need the best quality of service that can build direct relationships with customers [3].

Customers who receive these services can feel conformity with customer expectations from the performance of the company's services to be a factor that can survive and compete in the market. Therefore, we need the right methodology so that companies can identify their customers based on their level of loyalty to continue implementing campaigns that are in accordance with customer needs [4]. The company must be able to manage customers in overcoming the nature of customers who always have choices and make the company can be divided into two, namely customers with large profits or customers in making requests and choices so that the company feels difficulties. Service and price are two factors of satisfaction received by customers [5]. There are factors in influencing the quality of service for customers such as expected service, namely the service expected by the customer to be well received, so that it gets a positive value for the company and the perceived service exceeds the expected service, namely, the service is not well received by the customer resulting in a negative value [6] [7].

The increasingly modern era certainly requires media to help humans become more productive, moreover, the technology can assist in providing customer satisfaction so as to generate loyalty. diagrams, conversions in flowcharts are included in the SEM equation, there is a choice of input matrices and estimation techniques, assessing problems that have been identified, evaluating models, making model changes and interpretations [8]. The benefits obtained from the use of SEM are: relationships such as causality, validity, and rehabilitation can be tested, between direct and indirect variable effects can be seen, dependent and independent variables can be tested at the same time, measured indicator variables can affect the next variable office and also variables can measure directly will be through the variables in its indicators [9]. It takes a technology that can measure the extent of customer loyalty to the company by getting accurate, fast, and precise results in customer data. Not only that, hybrid is a form of digital technology service with a combination of computer machines that can analyze the wishes of customers or customers [10] [11]. A computer is a technological machine with an algorithm that can calculate customer transaction data. Recency Frequency Monetary (RFM), is a method used by marketing in recording or surveying customer activities in carrying out the time of the initial and last transaction (recency) the last time the customer made a transaction (recency), how often the customer made a transaction with the nominal amount of the transaction issued by the customer when making transactions (monetary) [12].

\section{Theoretical Review}

\subsection{Structural Equation Modeling}

Structural Equation Modeling is known as a static analysis method using a structural approach in solving a problem. In the1950s the use of SEM was used in the fields of social science, psychology, and others. This development was carried out by Karl in 1969 in introducing software when doing SEM statistical summation. Structural Equation Modeling can be grouped into mathematical or quantitative models that have an explanation of organizational system relationships and cannot be represented by combining iconic (analog) models. The modeling technique used is cross-sectional, linear, and complex. Confirmatory Factor Analysis in SEM is used to confirm the most dominant factors in a group of variables [13]. Regression weights in SEM are used to examine how big the relationship between variables is. There is a main requirement for using the SEM method by building a model with a hypothesis consisting of a structure and measurement model in the form of a diagram with the basis of theoretical justification of course [14].

The use of Structural Equation Modeling-Partial Least Square itself has been used in analyzing problems that often occur in human life and is applied in a decision support system with a simple description of the activities carried out in the presence of phenomena. As in the field of education, namely analyzing students in motivating institutions in tutoring [15], SEM is 
also used in the application of any factors in the Madurese community towards compliance with health protocols and it turns out that SEM has become a trend in the conventional and Islamic banking sectors in Indonesia to be able to attract customer trust [16]. The reason for applying the use of Structural Equation Modeling in this study is to be able to identify transactions carried out in influencing the bank to increase the total balance of business savings, with an increase in the number of balances at the bank, it can be seen how far the form of loyalty given by customers to the bank is due to customer data. in conducting transactions, the amount made can be seen from the time at the end of the transaction and the nominal amount. The bank can more easily build closeness with customers to be able to maintain the form of loyalty that has been given, this loyalty occurs with the existence of trust from customers because consumer use decisions affect information from various sources [17].

\subsection{Recency, Frequency, and Monetary}

Arthur Huges was a pioneer in introducing the RFM Model which has been widely used in the manufacturing, retail, and service industries. The use of a CRM model is used to measure the probability of customer value. According to Kumar and Reinartz (2012), the RFM methodology is based on recency, frequency, and monetary value. This technique uses 3 metrics to evaluate customer behavior and customer value. RFM techniques help organizations significantly, not only in identifying and targeting valuable customers with very high transaction opportunities, but also in campaign effectiveness for customers with lower transaction opportunities [18]. The e limitation of RFM is that RFM techniques can only be applied to customers with historical data available and not to lead data. The RFM technique is based on three customer attributes which include Recency of Purchase, Frequency of Purchase, and Monetary Value of Purchase. Can be interpreted as follows: Recency is a measure of how long the last transaction occurred in the customer. Frequency is a measure of how often customers make certain transactions at the Bank during a certain period. Monetary value is a measure of how big the volume of customer transactions is in a certain period. The general idea of RFM is to classify customers based on their RFM group resulting from their transaction behavior. The concept of RFM consists of three-dimensional aspects: Recency, which is research conducted over the years with a statistical display that can show that customer transactions that has been carried out recently will carry out transactions shortly. Frequency, which shows that customers regularly make purchases and will make these purchases at a later date. Monetary Value i.e. customers distribute materials (funds) to make purchases through a site.

The Recency Frequency Monetary (RFM) model is an old method that has been used for a long time and is very popular in its application to measure the relationship built with customers by making estimates using a database. RFM is an internal model that can be implemented in the field of marketing because there is a history of purchases and consumer browsing. The implementation can be seen from the initial customer grouping resulting in 27 groups that are divided based on their RFM scores. Each customer is assigned a corresponding code. Each customer has an R, F, and $\mathrm{M}$ value that may be higher or lower than the average R, F, and M values for all clients. Subscribers are coded 3 (for High), 2 (for medium), and 1 (for low) for their RFM, and so on for all subscribers. Furthermore, from the discriminant analysis obtained that the resulting group can be used to differentiate customers. The purpose of using the RFM Score is to predict customer behavior in the future [19] [20]. Therefore, banks need to translate customer behavior into numerical status so that it can be used for measuring customer loyalty.

\section{Findings}

Conducted for 4 (four) months from April 2016 to July 2016. The data source used is transaction data for business savings customers at Bank XYZ which includes customer profile 
data and transaction type data obtained from savings customer transaction data. XYZ Bank's business.

\subsection{SEM Analysis}

Determination of the transactions that have the most influence is carried out using the SEM Confirmatory Factor Analysis method, where Regression Weight is used to determine the transactions that most affect the Average Balance [21].

\subsection{Loyalty Variables}

Customer segmentation was developed using the RFM method. Variables in the RFM method include recency, frequency, monetary. For Recency, the variable to be measured is the last transaction per customer in 2016 [22]. For Frequency, the variable to be measured is the number of Transactions per customer (frequency) during the 2016 period, and for Monetary, the variable measured is the volume of transactions per customer in a period of 4 months in 2016 [23].

\subsection{RFM Analysis}

RFM analysis is Used to segment customers. The RFM analysis carried out in this study uses the Principal Component Analysis (PCA) method to calculate the relative weights of the $\mathrm{R}, \mathrm{F}$, and $\mathrm{M}$ metrics. Relative weights are used to calculate cumulative points for each customer. To segment customers based on RFM requires five steps.

- First, sorting customers based on transactions determined based on SEM results including recency; frequency; and monetary. For updating, the customer database is sorted from the newest transaction to the oldest transaction. The frequency is sorted from the highest transaction frequency to the lowest transaction frequency. The monetary value is obtained from the total volume of customer transactions for 4 months [24].

- Second, determine the binning score for each RFM group. The score is given based on the matrix $\mathrm{R}, \mathrm{F}$, and $\mathrm{M}$.

- Third, determine the order of the matrix R3, R2, R1, F3, F2, F1, and M3, M2, M1. The scores obtained for each of the PCA results $R, F$, and M were used to combine and generate the RFM point weights (333 to 111).

- Fourth, calculate the combination of points for each customer and divide them into 9 segmentation groups, starting from customers with the highest percentage of cumulative RFM points (333) to customers with the lowest cumulative RFM points (111) (see table 4.2). The higher the cumulative points earned from a customer, the more profitable that customer will be in the future.

- Fifth, conduct campaigns based on customer RFM categories.

\section{Conclusion}

Identification of influential transactions

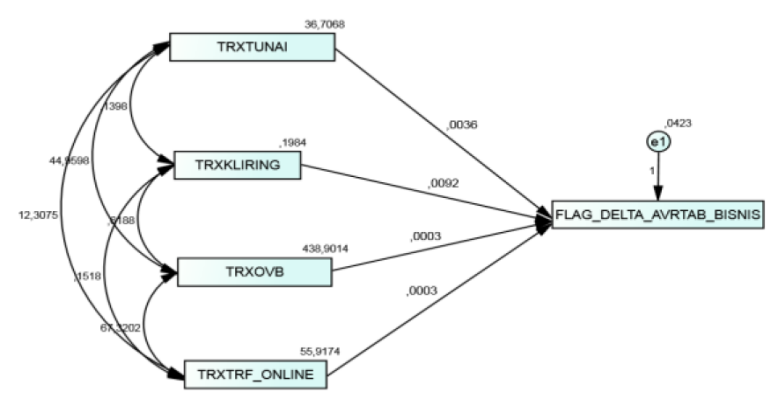

Figure 4.1. Path Diagram 
Regression Weights: (Group number l - Default model)

\begin{tabular}{ll|rrrrr} 
& & Estimate & S.E. & C.R. & P & Label \\
\hline FLAG_DELTA_AVRTAB_BISNIS <--- TRXTUNAI &, 004 &, 000 & 16,593 & $* * *$ & \\
\hline FLAG_DELTA_AVRTAB_BISNIS <--- TRXTRF_ONLINE &, 000 &, 000 & 1,902 &, 057 \\
\hline FLAG_DELTA_AVRTAB_BISNIS <--- TRXKLIRING &, 009 &, 003 & 3,387 & $* * *$ & \\
\hline FLAG_DELTA_AVRTAB_BISNIS <--- TRXOVB &, 000 &, 000 & 4,050 & $* * *$
\end{tabular}

Table 4.1. Regression Weight

From the results of Confirmatory Factor Analysis and Regression Weight on SEM which are used to test how big the relationship between the transaction variables obtained include Cash Deposits, Online Transfers, Clearing, Book Transfers, we analyze the transactions that have the most influence on the increase in the average balance, then the result is a "clearing" transaction for the most influential transaction variable [25]. What is meant by clearing transactions are transfer transactions originating from other Banks that enter Bank XYZ [26].

\subsection{RFM Segmentation RFM segmentation is}

done by binning process on Recency, Frequency, and Monetary.

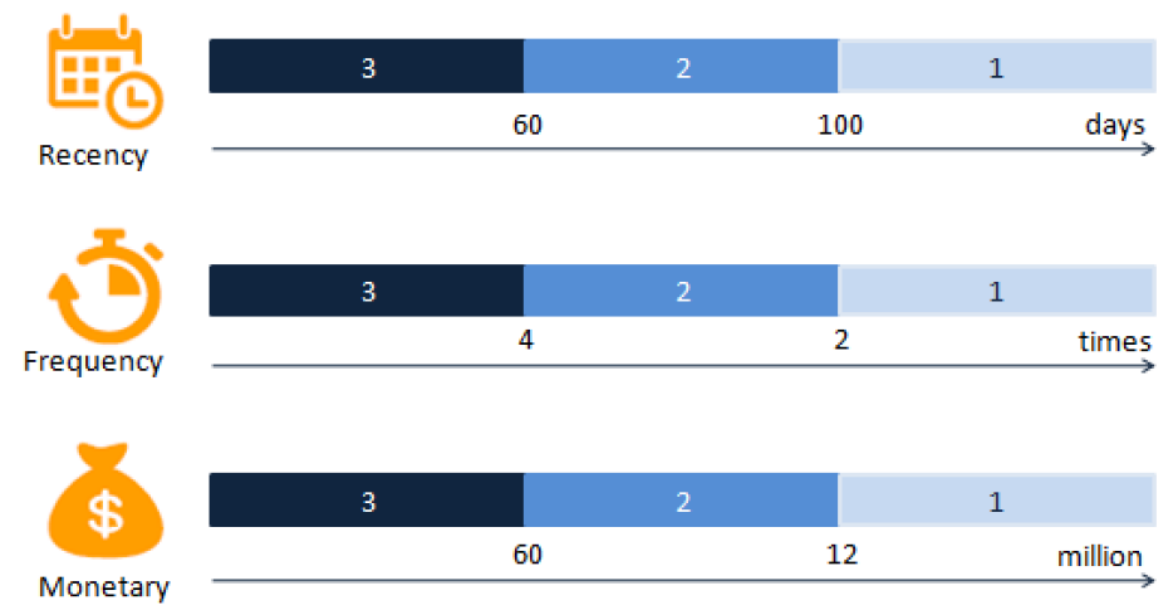

Figure 4.2. Binning RFM

Recency ranged from 3 beginnings ( $<60$ days, 60-100 days, and $>100$ days). Frequency ranges from 3 beginnings ( $>4 \operatorname{tr} x, 4-2 \operatorname{tr} x,<2 \operatorname{trx})$. and Monetary around 3 beginnings $(>60$ million, 60-12 million, $<12$ million) [27]. 


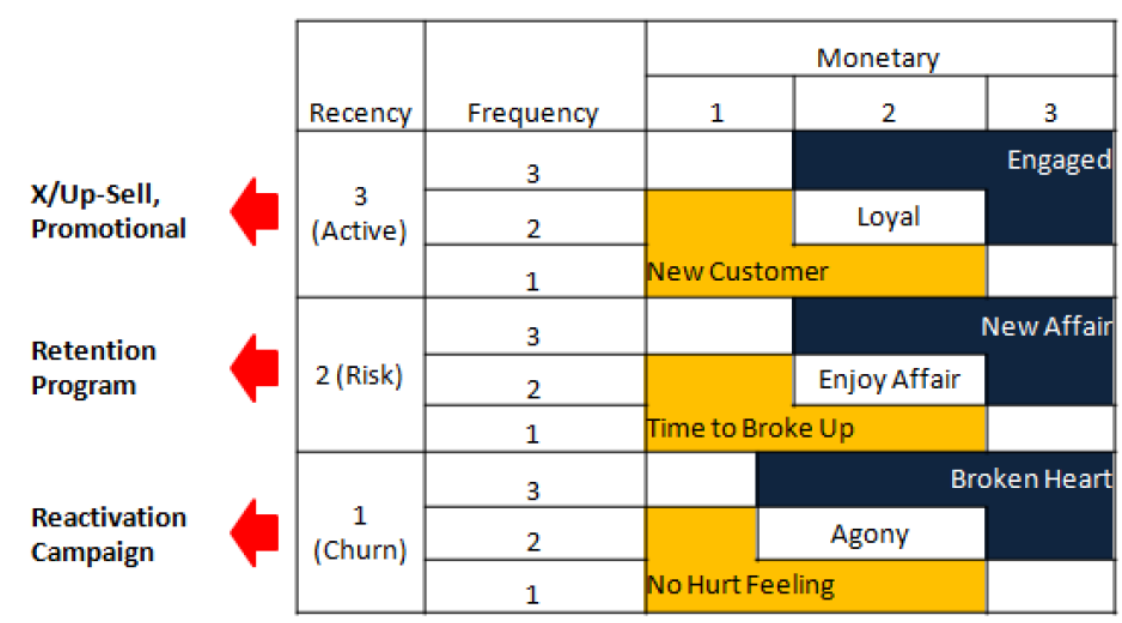

Table 4.2. Segmentation

RFM segmentation RFM divide the segmentation of customers based on the weight of RFM highest (333) to lowest (111) is divided into 9 categories segments: Engage, Loyal, New Customers, Affairs New, Enjoy Affair, Time to Break-up, Broken Heart, Suffering and Not There is Pain [27]. Naming segments can be customized by-products. The higher the cumulative RFM score, the higher the customer loyalty. Therefore customer segmentation is based on the RFM score [28].

\begin{tabular}{|c|c|c|c|c|c|c|}
\hline \multirow[b]{2}{*}{ Recency } & \multirow[b]{2}{*}{ Frequency } & \multicolumn{3}{|c|}{ Monetary } & \multirow{2}{*}{8375} & \multirow[b]{2}{*}{ Engaged } \\
\hline & & 1 & 2 & 3 & & \\
\hline \multirow{3}{*}{3 (Active) } & 3 & 271 & 1,794 & 5,620 & 2322 & Loyal \\
\hline & 2 & 760 & 1,411 & 961 & 3699 & New Cus \\
\hline & 1 & 1,788 & 1,151 & 640 & 4060 & New Affair \\
\hline \multirow{3}{*}{2 (Risk) } & 3 & 211 & 1,028 & 1,720 & 3664 & Enjoy Affair \\
\hline & 2 & 1,173 & 2,072 & 1,312 & 7602 & Time to \\
\hline & 1 & 3,963 & 2,465 & 1,381 & & \\
\hline \multirow{3}{*}{1 (Churn) } & 3 & 63 & 245 & 449 & 1660 & Broken Heart \\
\hline & 2 & 877 & 1,455 & 966 & 3477 & Agony \\
\hline & 1 & 5,912 & 3,378 & 1,959 & 10167 & $\begin{array}{l}\text { No Hurt } \\
\text { Feeling }\end{array}$ \\
\hline
\end{tabular}

Table 4.3. RFM Segmentation

Results of XYZ Bank's customer RFM segmentation show the customer population according to its RFM score from the highest to the lowest score. (see table 4.3).

\subsection{Campaign Strategy}

Results of this RFM score then become a reference for the Bank's strategy to carry out campaign activities to increase the average balance of Business Savings. Customers with $1,2,3$ segment RFM can be offered with Cross-Selling, Up-Selling, and promotion campaigns. Segments 4,5,6 can be offered with a retention program. Meanwhile, segment 7,8,9 can be offered with a reactivation program (see Table 4.3) [29]. 


\section{References}

[1] F. S. Lubis, A. P. Rahima, M. I. H. Umam, and M. Rizki, "Analisis Kepuasan Pelanggan dengan Metode Servqual dan Pendekatan Structural Equation Modelling (SEM) pada Perusahaan Jasa Pengiriman Barang di Wilayah Kota Pekanbaru," J. Sains, Teknol. dan Ind., vol. 17, no. 1, pp. 25-31, 2020.

[2] A. Wibowo and A. R. Handoko, "Segmentasi Pelanggan Ritel Produk Farmasi Obat Menggunakan Metode Data Mining Klasterisasi Dengan Analisis Recency Frequency Monetary (RFM) Termodifikasi," J. Teknol. Inf. dan Ilmu Komput, 2020.

[3] H. Rohaeni and N. Marwa, "Kualitas Pelayanan Terhadap Kepuasan Pelanggan," J. Ecodemica, vol. 2, no. 2, 2018.

[4] R. Oktarini, "Pengaruh Kualitas Pelayanan Dan Harga Terhadap Kepuasan Pelanggan Pengguna Jasa Aplikasi Gojek Di Kota Tangerang," J. Sekr. Univ. Pamulang, vol. 6, no. 2, pp. 248-257, 2020.

[5] A. Gofur, "Pengaruh kualitas pelayanan dan harga terhadap kepuasan pelanggan," $J$. Ris. Manaj. Dan Bisnis Fak. Ekon. UNIAT, vol. 4, no. 1, pp. 37-44, 2019.

[6] E. D. Supandi, "Pengaruh Remunerasi dan Motivasi Terhadap Kinerja Pegawai UIN Sunan Kalijaga Yogyakarta dengan Menggunakan Structural Equation Modelling," in PRISMA, Prosiding Seminar Nasional Matematika, 2020, vol. 3, pp. 84-94.

[7] I. Ilamsyah, R. Wulandari, and R. R. Fahreza, "Web Design Visual Comic Communication As A Visual Based Learning Media," IAIC Trans. Sustain. Digit. Innov., vol. 2, no. 1, pp. 1-10, 2020.

[8] N. Hermansyah, "Model Pengukuran Kualitas Layanan Nasabah Mesin Hybrid Bank BRI Dengan Metode Structural Equation Model (SEM)," J. IIm. Humanika, vol. 3, no. 3, pp. 53-58, 2020.

[9] Y. H. Chrisnanto and A. Kanianingsih, "Pengelompokan Ekuitas Pelanggan Berbasis Recency Frequency Monetary (RFM) Menggunakan K-Means Clustering." vol, 2019.

[10] N. R. Syarif and W. Windarto, "Implementasi Algoritma Fuzzy C-means Dan Metode Recency Frequency Monetary (Rfm) Pada Aplikasi Data Mining Untuk Pengelompokan Pelanggan," Sebatik, vol. 22, no. 2, pp. 88-94, 2018.

[11] A. Suryadi, P. T. Asmoro, and A. Solihin, "Hybrid Electric Power Plant Using Wind Turbine Savonius Helix and Solar Cell as an Alternative Power Source in the Lightning Tower at Flashing Lights," ADI J. Recent Innov., vol. 1, no. 1, pp. 1-6, 2019.

[12] N. Lutfiani, U. Rahardja, and I. S. P. Manik, "Peran Inkubator Bisnis dalam Membangun Startup pada Perguruan Tinggi," J. Penelitan Ekon. dan Bisnis, vol. 5, no. 1, pp. 77-89, 2020.

[13] M. Darwin and K. Umam, "Indirect Effect Analysis on Structural Equation Modeling (Comparative Study of Using Amos and SmartPLS Software)," Nucleus, vol. 1, no. 02, pp. 50-57, 2020.

[14] A. U. Zaelani, T. Husain, and A. Budiyantara, "Analisis Simulasi Sistem Penunjang Keputusan: Model Matematis Dengan Pendekatan Goodness-of Fit Berbasis Structural Equation Model," SMARTICS J., vol. 6, no. 1, pp. 10-16, 2020.

[15] R. Latumeten, Y. A. Lesnussa, and F. Y. Rumlawang, "Penggunaan Structural Equation Modeling (Sem) untuk Menganalisis Faktor yang Mempengaruhi Loyalitas Nasabah (Studi Kasus: PT Bank Negara Indonesia (BNI) KCU Ambon)," Sainmatika J. IIm. Mat. dan Ilmu Pengetah. Alam, vol. 15, no. 2, pp. 76-83, 2018.

[16] M. T. Daulay and A. Sanny, "Analysis of Structural Equation Modeling Towards Productivity and Welfare of Farmer's Household in Sub-District Selesai of Langkat Regency," Int. J. Res. Rev., pp. 117-123, 2019.

[17] C. Andreas, S. Priandi, A. N. M. B. Simamora, and M. F. F. Mardianto, "Analisis Hubungan Media Sosial dan Media Massa dalam Penyebaran Berita Hoaks berdasarkan Structural Equation Modeling-Partial Least Square," MUST J. Math. Educ. Sci. Technol., vol. 6, no. 1, pp. 81-96, 2021.

[18] S. K. Mariniharsi, T. Hidayati, and I. Tricahyadinata, "Pengaruh karakteristik individu 
dan karakteristik pekerjaan terhadap kepuasan kerja serta kinerja pegawai negeri sipil," J. IImu Manaj. Mulawarman, vol. 4, no. 1, 2020.

[19] E. Erfiansyah and R. Rustandi, "ANALISIS MANFAAT AUDIT DITINJAU DARI PERSPEKTIF KLIEN AUDIT," J. IIm. MEA (Manajemen, Ekon. Akuntansi), vol. 2, no. 3, pp. 68-83, 2018.

[20] M. I. Sanni and D. Apriliasari, "Blockchain Technology Application: Authentication System in Digital Education," Aptisi Trans. Technopreneursh., vol. 3, no. 2, pp. 37-48, 2021.

[21] D. Himawati, "Pengaruh Word of Mouth dan Manfaat Terhadap Keputusan Menggunakan E-Wallet Dana Melalui Kepercayaan Pelanggan di Jabodetabek," INOBIS J. Inov. Bisnis dan Manaj. Indones., vol. 4, no. 3, pp. 424-436, 2021.

[22] K. Arora and A. S. Bist, "Artificial intelligence based drug discovery techniques for covid-19 detection," Aptisi Trans. Technopreneursh., vol. 2, no. 2, pp. 120-126, 2020.

[23] A. Febriani and S. A. Putri, "Segmentasi Konsumen Berdasarkan Model Recency, Frequency, Monetary dengan Metode K-Means," J. Ind. Eng. Manag. Syst., vol. 13, no. 2, 2020.

[24] Y. O. Pailan, Y. H. Chrisnanto, and A. I. Hadianna, "Segmentasi Loyalitas Pelanggan Berbasis RFM (Recency, Frequency, Monetary) Menggunakan K-Means pada PD. Persada Ikan," Pros. SISFOTEK, vol. 4, no. 1, pp. 167-171, 2020.

[25] S. Bin Kamarudin and M. S. Taat, "Pengaruh Faktor-faktor Tekanan Kerja dalam kalangan Guru di Sekolah Menengah: Satu Analisis Persamaan Struktur (SEM-PLS)," Malaysian J. Soc. Sci. Humanit., vol. 5, no. 11, pp. 104-115, 2020.

[26] S. I. Murpratiwi, I. G. A. Indrawan, and A. Aranta, "ANALISIS PEMILIHAN CLUSTER OPTIMAL DALAM SEGMENTASI PELANGGAN TOKO RETAIL," J. Pendidik. Teknol. dan Kejuru., vol. 18, no. 2, pp. 152-163, 2021.

[27] M. Khatami, A. Alexander, and R. B. Alfarizky, "PAK BEN: INOVASI APLIKASI E-COMMERCE BAGI UMKM BENGKEL DAN BENSIN ECERAN DALAM MENCAPAI SustainABLE DEVElOPMENT GOALS 2030," J. Ilm. Penal. dan Penelit. Mhs., vol. 5, no. 2, pp. 158-178, 2021.

[28] A. Khatoon, "A blockchain-based smart contract system for healthcare management," Electron., vol. 9, no. 1, 2020, doi: 10.3390/electronics9010094.

[29] F. Agustin, Q. Aini, A. Khoirunisa, and E. A. Nabila, "Utilization of Blockchain Technology for Management E-Certificate Open Journal System," Aptisi Trans. Manag., vol. 4, no. 2, pp. 133-138, 2020. 